\title{
Principal ocular glands in the desert rodent Gerbillus tarabuli: morpho-functional adaptive analysis
}

\author{
Ouanassa Saadi-Brenkia ${ }^{12^{*}}$ (D) Nadia Haniche ${ }^{2}$ and Saida Lounis ${ }^{1,2}$
}

\begin{abstract}
Background: Desert rodent, Gerbillus tarabuli, is a seed-eating animal and do not require drinking water. It depends upon metabolic water. Understanding the functional characteristics of ocular glands which produce a watery lacrimal fluid is of interest. In the present study, we described the macroscopic anatomy and microscopic structure of the paraorbital glands in tarabul's gerbil.
\end{abstract}

Results: There are up to four distinct orbital glands: lacrimal (LG), Harderian (HG), Meibomian (MG), and conjunctival mucous glands. Each eye has three eyelids, the main upper and lower lids and a third lid hidden between them in the inner corner of the eye. The LG is bipartite, situated on the dorsolateral aspect of the eyeball. The HG is large and localized deep in the orbit. The MG is found in the dense connective tissue plate. Upon light microscopic examination, the LG is an acinar gland; its secretory cells have mucous and serous granular cytoplasm. The endpieces of HG consist of tubuloalveoli, with two cellular types: prismatic vacuolated cells and pyramidal basophilic cells. The MG acini are closely arranged one after another. Each acinus contains a basal layer of myoepithelial cells and a mass of rounded, vacuolated cells. The nictitating membrane is formed by a semilunar fold of conjunctiva, supported by a hyaline cartilage. Numerous goblet cell clusters are detected in the covering conjunctiva particularly in the bulbar conjunctiva. Mucin glycoproteins appear to be abundant in the precorneal tear film, probably acting against desiccation stress.

Conclusions: Based on the data from this study, it could be concluded that the orbital glands of gerbil are welldeveloped, similar to other mammals.

Keywords: Anatomy, Histology, Gerbillus tarabuli, Ocular glands

\section{Background}

Rodents from arid and semiarid habitats are faced with a dry, dusty, and windy climate. They are adapted to arid conditions, where the spatial and temporal availability of free water is limited or scarce. Gerbillus tarabuli (tarabul's gerbil) which belongs to the family Muridae (subfamily Gerbillinae) is a nocturnal species independent of

\footnotetext{
* Correspondence: saadianissa@yahoo.fr

'Department of Biology, University of Boumerdes Faculty of Sciences, Avenue de l'indépendance, 35000 Boumerdes, Algeria

2Laboratory of Biology and Physiology of Organisms, Neurobiology, Scientific and Technical University Houari Boumediene, 16111 Algiers, Algeria
}

any free water or even of moist food. It eats primarily dry, high carbohydrate seeds.

Tears secreted by the ocular glands have an important role in maintaining the integrity of the ocular surface and the preservation of visual acuity. The ocular glands as well as secretory components of the ocular surface, including the conjunctiva goblets cells, act as a functional unit (Stern et al., 2004). They produce the ocular tear film which is complex containing multiple layers (Argüeso \& Gipson, 2001; Bron et al., 2004). Its major function is to provide an optically smooth surface over the cornea and retarding evaporation from the eye (Bron et al., 2004; King-Smith et al., 2008; Rantamaki et al., 2012).

\section{Springer Open}

(C) The Author(s). 2020 Open Access This article is licensed under a Creative Commons Attribution 4.0 International License, which permits use, sharing, adaptation, distribution and reproduction in any medium or format, as long as you give appropriate credit to the original author(s) and the source, provide a link to the Creative Commons licence, and indicate if changes were made. The images or other third party material in this article are included in the article's Creative Commons licence, unless indicated otherwise in a credit line to the material. If material is not included in the article's Creative Commons licence and your intended use is not permitted by statutory regulation or exceeds the permitted use, you will need to obtain permission directly from the copyright holder. To view a copy of this licence, visit http://creativecommons.org/licenses/by/4.0/. 
In addition, it was reported that the tear layer maintains the health of the cells on the ocular surface by providing nourishment and removal of waste products and also protects them from environment. Studies of the orbital glands were earlier conducted in many species of animals (AbouElmagd, 1992; Djeridane, 1992; Gargiulo et al., 1999; Klećkowska-Nawrot \& Dzięgiel, 2007; Martin et al., 1988; Mohammadpour, 2009; Rehorek et al., 2010; Sakai, 1989). It was revealed that the anatomical structure of these glands is characterized by great variability (Chieffi et al., 1993; Dimitrov, 2011; Dimitrov \& Genchev, 2011; Payne, 1994; Rehorek et al., 2005). In all mammalian species, the lacrimal gland (LG) is located in the outer canthus while the Harderian gland (HG) is situated in the inner canthus of the orbit. The LG as was reported by Gargiulo et al. (Gargiulo et al., 1999) and Aldana Marcos, Cintia Ferrari, Cervino, and Affanni (Aldana Marcos et al., 2002) is a mixed gland consisting of tubulo-acinar units. On the other hand, the HG in mammals is defined as a lipid-secreting tubuloalveolar ocular gland (Payne, 1994; Sakai, 1981) and similarly in desert rodent by Djeridane (Djeridane, 1992) and SaadiBrenkia, Haniche, and Bendjelloul (Saadi-Brenkia et al., 2013). According to Leeson (1963), the MGs have been described by Duke-Elder and Wybar (Duke-Elder \& Wybar, 1961) as consisting of long tubes embedded in the tarsal plate and opening onto the surface at the lid margin.

The main ocular glands have received scant attention in desert rodent. Since it is well known that the lacrimal gland secretes a watery secretion, the anatomical and histological data are extremely important not only for comparative morphology but also in experimental and biomedical investigations. The purpose of our study is to examine the macroscopic and microscopic anatomy of the glands involved in the tear film production in desert gerbil.

\section{Methods}

This study was carried out on ten adult gerbils (five males and five females), ranging in weight from 23 to 45 $\mathrm{g}$ each. They were trapped in the desert of Beni-Abbes, region distant of $1250 \mathrm{~km}$ from the capital Algiers. They were housed in the animal facility of the Research Unit of dry area (URZA). The animals were cared for in accordance with the criteria outlined in the "Guide for the Care and Use of Experimental Animals" prepared by the National Academy of Sciences and published by the National Institute of Health. Gerbils were anesthetized by intraperitoneal (i.p.) injection with $10 \mathrm{mg} / \mathrm{kg}$ of ketamine hydrochloride then sacrificed by decapitation. The eyes with surrounding eyelids were dissected and fixed in $10 \%$ buffered formalin overnight. The samples were rinsed in water, dehydrated in ethanol, and embedded in paraffin. Five- to $7-\mu \mathrm{m}$-thick serial longitudinal sections from each sample were cut with a microtome (Leica
RM2125RT). The sections were deparaffinized and stained with hematoxylin-eosin for morphological description and Masson trichrome and Van Gieson for connective tissue and collagen fiber identification. The Periodic acid-Schiff procedure was used to stain for mucosubstances contained in goblet cells. They were evaluated using a Zeiss light microscope and images obtained using a Canon camera. Histological auto fluorescence studies were performed in unstained paraffin sections using a fluorescence microscope (450-490-nm filter) (Ortiz et al., 2001).

\section{Results}

We did not observe gender differences anatomically or histologically in samples.

\section{Macroscopic analysis}

The lids are composed of different layers which are superimposed from the conjunctiva to the external integument. MGs (tarsal glands) are located on the inner aspect of the main eyelids, and their orifices are visible along the free lid margin (Fig. 1a, b).

Gerbillus tarabuli has a transparent or translucent third eyelid or nictitating membrane, underneath the other two eyelids. The HG is a deep structure, connecting to the deep aspect of the nictitans membrane, filling the medial and posterior aspect of the orbit (Fig. 1c).

The gerbil contains a bipartite dorsal lacrimal gland. It appears as a pale structure, which was macroscopically difficult to distinguish from the surrounding adipose tissue (Fig. 1d).

\section{Microscopic analysis Conjunctiva and MGs}

The conjunctiva is a thin continuous mucous membrane lining the inner surface of the eyelids and much of the anterior surface of the eye. Three distinct areas of the conjunctiva are recognized: the bulbar conjunctiva, the palpebral conjunctiva, and the conjunctiva lining the fornix. The bulbar surface possesses a stratified epithelium and a lamina propria formed by dense connective tissue (Fig. 2A). The palpebral surface is composed of a columnar prismatic epithelium rich in clusters of goblet cells (Fig. 2B, B'). The eyelid skin is supported by connective tissue that constitutes the tarsal plate. It contains tarsal glands or MGs, orbicularis muscle, and Muller muscle. MGs are sebaceous glands embedded within the tarse plate of the upper and lower lids. The glandular units consist of acini arranged tightly in spherical shape; the acinar cells are completely occupied by lipid droplets (Fig. 2B, C). 



Fig. 1 Macroanatomy of the ocular glands and eyelids of Gerbillus tarabuli. a The upper eyelid (arrow). b The lower eyelid with Meibomium glands (arrow). c Lateral view of the gerbil eye, showing the location, lobulation, and color of HG; the third eyelid is attached to HG (arrow). $\mathbf{d}$ Lacrimal gland position (green circle), shape and color

\section{Third eyelid}

Near the corner of the eye, the conjunctiva forms a large fold and constitutes then a third eyelid or nictitating membrane. The central axis of the third eyelid contains a band of hyaline cartilaginous tissue. On both sides of this cartilaginous plate, there is a cellular conjunctive tissue (Fig. 2D).

\section{Harderian gland}

The gerbil HG is surrounded by a thin connective tissue capsule which sends septa dividing the gland into lobules of varying size. The endpieces of the gland are tubuloalveolar with a wide central lumen, lined by a pseudostratified columnar epithelium (Fig. 2D, D'). Two glandular cell types can be distinguished: Prismatic cells account for the majority of cells, which are characterized by a highly vacuolated cytoplasm. Pyramidal cells are less common; they have a basophilic cytoplasm with numerous granules PAS+. There are no recognizable excretory ducts in the glandular parenchyma. Often, the glandular lumen contains pigment accretions. Fluorescence microscopy has confirmed the presence of porphyrins (Fig. 2E, F).

\section{Lacrimal gland}

The LG is surrounded by fibrous tissue. It is a compact structure, organized in acinar units, which are separated into lobules by a thin connective tissue (Fig. 3a). The interstitium is rich in blood vessels, nerves, and excretory ducts. The lumen of each acinus is lined by columnar epithelial cells. Two types of secretory cells are observed, according to their morphologic appearance. Serous cells have a basophilic cytoplasm containing rounded nuclei and mucus-producing cells with flattened nuclei basally located. Thus, the gland is seromucous, but the mucous acini make up the largest part (Fig. 3b).

\section{Discussion}

Desert-dwelling rodents display physiological features that favor body water conservation, such as efficient kidney function, low fecal water content, and comparatively low evaporative water loss (Degen, 1997). Thus, for the optical integrity, they must keep the eye wet and clean in this dry environment.

\section{Conjunctiva and Meibomian glands}

The conjunctival epithelium forms a physical protective barrier through goblet cell secretions. It contributes to the formation and maintenance of a "tear film," which produces protective scaffolding over the ocular surface (Chen Wensheng et al., 2003). In gerbils, goblet cells in the conjunctiva are numerous and gathered in clusters in the bulbar side, as was reported in rat by Setzer, 

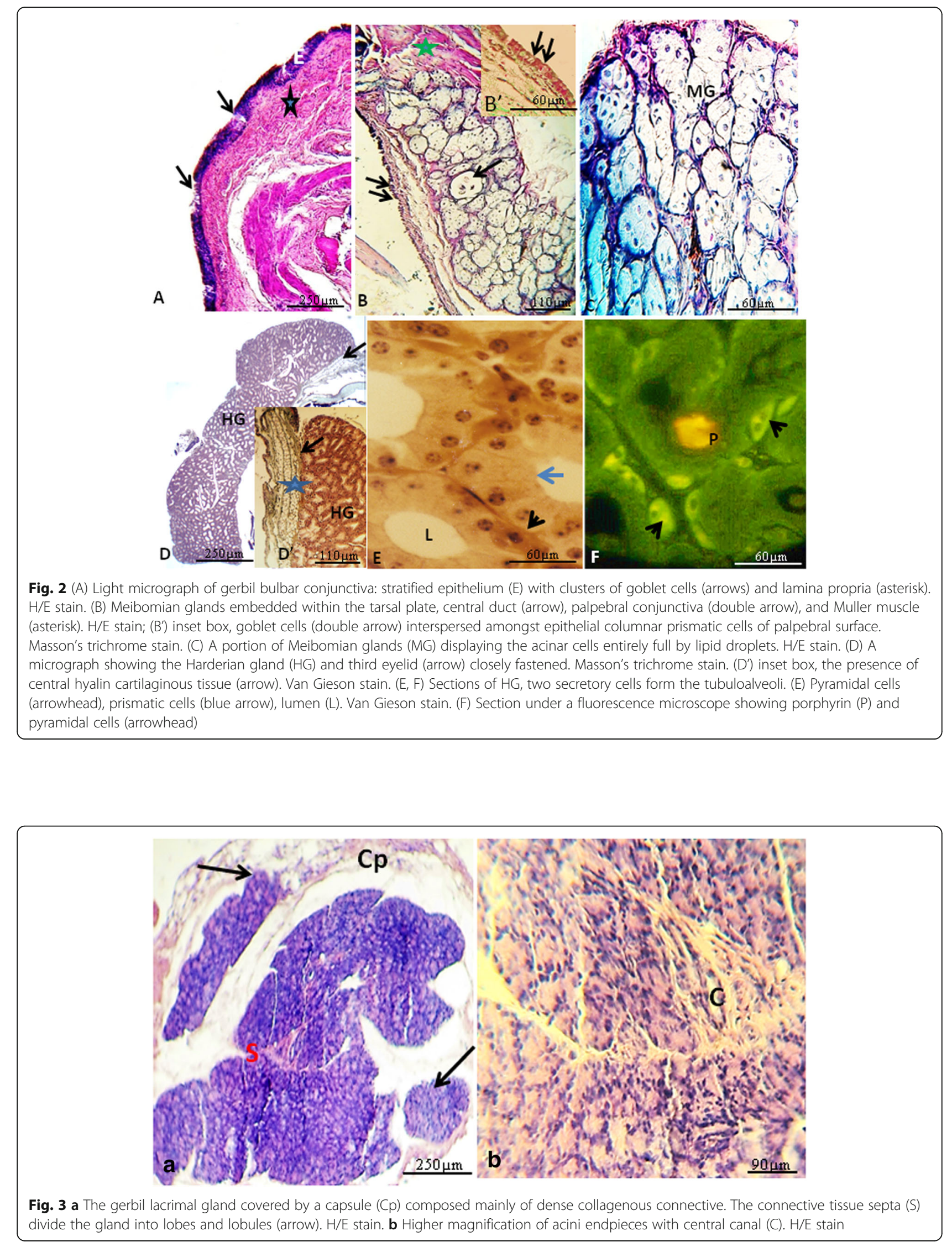
Nichols, and Dawson (Setzer et al., 1987) and in Mongolian gerbil by Micali et al. (Micali et al., 1998). The MGs lie inserted in the conjunctival side of the tarsal plate, and histologically, they confirmed the description of the tarsal glands set by Duke-Elder and Wybar (Duke-Elder \& Wybar, 1961) based on light microscopy. As reported by Tiffany (Tiffany, 1987), the eyelid margin is the source of physiologically important lipid secretion, meibum. These lipids must be an effective barrier to tear evaporation in this species.

\section{Third eyelid}

The gerbil's third eyelid or nictitating membrane appears well-developed. In agreement with Sisson and Grossman (Sisson \& Grossman, 1974), the third eyelid is a semilunar fold of the conjunctiva in the medial angle of the eye. It is supported by a piece of cartilage. Our study shows a hyaline cartilage and many goblet cells at the bulbar surface of the membrane. The same findings were described in albino rat, cattle, and small ruminants (Bisaria \& Bisaria, 1978; Dellmann \& Eurell, 1998; Schlegel et al., 2001). According to Saito, Watanabe, and Kotani (Saito et al., 2004) and Umeda et al. (Umeda et al., 2010), beside its function as a mechanical protection barrier for ocular surface, the third eyelid is important for the distribution of tears and contributes to their production through mucin cells.

\section{Harderian gland}

The HG is the largest among ocular glands in gerbil. In all rodents studied, the HG is a well-developed gland situated behind the ocular globe (Brownscheidle \& Niuwenhuis, 1978; Johnston et al., 1985; Lopez et al., 1993; Watanabe, 1980). The glandular parenchyma is organized in lobules and the secretory units are tubuloalveolar. The epithelium is pseudostratified with two cell types, columnar acidophilic cells, analogous to single cells in other desert rodents (Djeridane, 1996; Johnston et al., 1983; Sabry et al., 2000), and pyramidal basophilic cells remarkable by their aspect and their situation in the secretory epithelium. They have many PAS+ granules indicating glycoprotein storage (Saadi-Brenkia et al., 2013). All their histological characteristics are comparable to those observed in cell type III in desert rodents by Djeridane (Djeridane, 1996). But glycoprotein granules encountered in the Gerbillus tarabuli gland have not previously been detected in these species. They were described in HG cells of dolphin (Bodyak \& Stepanova, 1994), in tree shrew (Pradidarcheep et al., 2003), and in armadillo of South America (Aldana Marcos \& Affanni, 2005). The presence of porphyrins in the glandular lumina as solid accretions was previously indicated by Chieffi et al. (Chieffi et al., 1996) in other species of rodents.

\section{Lacrimal gland}

The principal lacrimal gland of desert rodents has not been previously investigated. The gerbil possesses a bipartite dorsal lacrimal gland; it appears as a pale structure. These findings agree with those of Sinha and Calhoun (Sinha \& Calhoun, 1966) in ruminants and Veiga Neto, Tamaga, Zorzetto, and Dallpai (Veiga Neto et al., 1992) in primates. Our histological analysis shows that the lacrimal gland is organized in lobules separated by septa of connective tissue sent from the capsule that surrounds the gland. Serous and mucous acini are present. The gland is predominantly mucous. These mixed glands have been described in many mammals (Allen et al., 1972; Gargiulo et al., 1999; Kühnel \& Scheele, 1979). In contrast, rat lacrimal glands are defined as being purely serous (Lorber, 1989).

\section{Conclusion}

To conclude, there seems to be nothing unusual in the morphological aspect of gerbil's orbital glands; thus, the current work has provided normative data on the main ocular glands of this desert species, which are represented by Meibomian glands and Harderian gland. They constitute the principal source of the lipid layer; that must be an effective barrier to avoid water evaporation from dry air of arid environment. The aqueous layer is formed by the lacrimal glands. Mucin glycoproteins seem to be a major functional constituent of the preocular tear film in gerbil. They are produced by conjunctival goblet cells, Harderian glands, and lacrimal glands. It could be suggested that more research should be performed for future comparative studies with rat and human. This is particularly important as there is growing evidence of the link between lowered levels of mucins and pathologic features of dry eyes.

\section{Acknowledgements \\ The authors thank the personnel of the Research Station of Dry Land of Beni-Abbes.}

\section{Authors' contributions}

OS-B conceived and designed the study, NH prepared the figures, and SL revised the manuscript. All authors have participated in the elaboration of this work and have approved for this submission.

\section{Funding}

The research is funded by Ministry of Higher Education and Research.

\section{Availability of data and materials}

Data sharing is not applicable to this article as no datasets were generated or analyzed during the current study.

\section{Ethics approval and consent to participate}

All animals were cared for in accordance with the criteria outlined in the "Guide for the Care and Use of Experimental Animals" prepared by the National Academy of Sciences and published by the National Institute of Health following approval by the Institutional Animal Care Committee of the Algerian Higher Education and Scientific Research. 


\section{Consent for publication}

Not applicable.

\section{Competing interests}

The authors declare that they have no competing interests.

Received: 8 February 2020 Accepted: 4 June 2020

Published online: 23 June 2020

\section{References}

Abou-Elmagd, A. (1992). Ultrastructural observations on myoepithelial cells and nerve terminals in the camel Harderian gland. Anatomy and Embryology, 185, 501-507.

Aldana Marcos, H. J., \& Affanni, J. M. (2005). Anatomy, histology, histochemistry and fine structure of the Harderian gland in the South American armadillo (Chaetophractus villosus) (Xenarthra, Mammalia). Anatomy and Embryology, 209, 409-424

Aldana Marcos, H. J., Cintia Ferrari, C., Cervino, C., \& Affanni, J. M. (2002). Histology, histochemistry and fine structure of the lacrimal and nictitans gland in the South American armadillo Chaetophractus villosus (Xenarthra, Mammalia). Experimental Eye Research, 75(6), 731-744.

Allen, M., Wright, P., \& Reid, L. (1972). The human lacrimal gland. A histochemical and organ culture study of the secretory cells. Archives of Ophthalmology, 88(5), 493-497.

Argüeso, P., \& Gipson, I. K. (2001). Epithelial mucins of the ocular surface: Structure, biosynthesis and function. Experimental Eye Research, 73(3), 281289

Bisaria, K. K., \& Bisaria, S. D. (1978). The third eyelid in the albino rats (a histological study). Indian Journal of Ophthalmology, 26(2), 25-28.

Bodyak, N. D., \& Stepanova, L. V. (1994). Harderian gland ultrastructure of the black sea bottlenose dolphin (Tursiops truncatus ponticus). Journal of Morphology, 220, 207-221.

Bron, A. J., Tiffany, J. M., Gouveia, S. M., Yokoi, N., \& Voon, L. W. (2004). Functional aspects of the tear film lipid layer. Experimental Eye Research, 78, 347-360.

Brownscheidle, C. M., \& Niuwenhuis, R. J. (1978). Ultrastructure of the Harderian gland in male albino rats. The Anatomical Record, 190, 735-754.

Chen Wensheng, I. M., Yamaki, K., Sakuragi, S., \& Ishikawa, M. (2003). Wistar rat palpebral conjunctiva contains more slow-cycling stem cells that have larger proliferative capacity: Implication for conjunctival epithelial homeostasis. Japanese Journal of Ophthalmology, 47, 119-128.

Chieffi, G., Baccari, G. C., Di Matteo, L., d'Istria, M., Minucci, S., \& Varriale, B. (1996). Cell biology of the Harderian gland. International Review of Cytology, 168, 1 80.

Chieffi, G., Minucci, S., \& Di Matteo, L. (1993). The orbital glands of the terrapin Pseudemys scripta in response to osmotic stress: A light and electron microscope study. Journal of Anatomy, 183, 21-33.

Degen, A. A. (1997). Water requirements and water balance. Ecophysiology of small desert rodents. Berlin: Springer Verlag.

Dellmann, H. D., \& Eurell, J. (1998). Textbook of veterinary histology, (5th ed., pp. 63-67). Baltimore: Williams \& Wilkins.

Dimitrov, D. (2011). Intraorbital glands in turkey broilers. III. Lacrimal gland histometry. Journal of Agricultural Science and Technology, 3, 327-329.

Dimitrov, D. S., \& Genchev, A. G. (2011). Comparative morphometric investigations of intraorbital glands in Japanese quails (Coturnix coturnix japonica). Bulgarian Journal of Veterinary Medicine, 14, 124-127.

Djeridane, Y. (1992). The Harderian gland of desert rodents: A histological and ultrastructural study. Journal of Anatomy, 180, 465-480.

Djeridane, Y. (1996). Comparative histological and ultrastructural studies of the Harderian gland of rodents. Microscopy Research and Technique, 34(1), 28-38.

Duke-Elder, S., \& Wybar, K. C. (1961). The anatomy of the visual system. In S. Duke-Elder (Ed.), In System of ophthalmology, vol. 2, (pp. 559-581). London: Kimpton.

Gargiulo, A. M., Coliolo, P., Ceccarelli, P., \& Pedini, V. (1999). Ultrastructural study of sheep lacrimal gland. Veterinary Research, 30, 345-351.

Johnston, H. S., McGadey, J., Thompson, G. G., Moore, M. R., Breed, W. G., \& Payne, A. P. (1985). The Harderian gland, its secretory duct and porphyrin content in the Plains mouse (Pseudomys australis). Journal of Anatomy, 140, 337-350.

Johnston, H. S., McGadey, J., Thompson, G. G., Moore, M. R., \& Payne, A. P. (1983). The Harderian gland, its secretory duct and porphyrin content in the Mongolian gerbil (Meriones unguiculatus). Journal of Anatomy, 137, 615-630.
King-Smith, P. E., Nichols, J. J., Nichols, K. K., Fink, B. A., \& Braun, R. J. (2008). Contributions of evaporation and other mechanisms to tear film thinning and break-up. Optometry and Vision Science, 85, 623-630.

Klećkowska-Nawrot, J., \& Dzięgiel, P. (2007). Morphology of the third eyelid and superficial gland on pig fetuses. Anatomia, Histologia, Embryologia, 36, 428432.

Kühnel, W. S., \& Scheele, G. (1979). Zur Feinstruktur der glandula lacrimalis des Schweins. Anatomischer Anzeiger, 145, 87-10.

Leeson, T S. (1963) Tarsal (meibomian) glands of the rat. Br J Ophthalmol, 47, 222-231.

Lopez, J. M., Tolivia, J., Alvarez-Uria, M., Payne, A. P., McGadey, J., \& Moore, M. R. (1993). An electron microscopic study of the Harderian gland of the Syrian Hamster with particular references to the process of formation and discharge of the secretory vacuoles. The Anatomical Record, 233(3), 342-352.

Lorber, M. (1989). Elastic fibers in the rat exorbital lacrimal gland duct system. Investigative Ophthalmology \& Visual Science, 30(9), 2002-2011.

Martin, C. L., Munnell, J., \& Kawsan, R. (1988). Normal ultrastructure and histochemical characteristics of canine lacrimal glands. American Journal of Veterinary Research, 49(9), 1566-1572.

Micali, A., Puzzolo, D., Pisani, A., Arco, A. M., Bruschetta, D., Santoro, G., \& Aragona, P. (1998). Ultrastructural study of the conjunctival epithelium in the Mongolian gerbil (Meriones unguiculatus). Ophthalmic Research, 30, 244-254.

Mohammadpour, A. A. (2009). Morphological and histological study of superior lacrimal gland of third eyelid in camel (Camelus dromedarius). Iranian Journal of Veterinary Research, Shiraz University, 10, 334-338.

Ortiz, G. G., Feria Velasco, A., Falcon Franco, M. A., Bitzer Quintero, O. K., Garcia, J. J., Rosales, S. A., ... Reiter, R. J. (2001). Different patterns in the histology and autofluorescence of the Harderian glands of the Syrian Hamster, rat, mouse, Mongolian gerbil and guinea pig. Anatomia, Histologia, Embryologia, 30, 107-115.

Payne, A. P. (1994). The harderian gland: A tercentennial review. Journal of Anatomy, 185, 1-49.

Pradidarcheep, W., Asavapongpatana, S., Mingsakul, T., Poonkhum, R., Nilbu-nga, S., \& Somana, R. (2003). Light and electron microscopic features of the orbital Harderian gland in the common tree shrew (Tupaia glis). Journal of Morphology, 255, 328-336.

Rantamaki, A. H., Javanainen, M., Vattulainen, I., \& Holopainen, J. M. (2012). Do lipids retard the evaporation of the tear fluid? Investigative Ophthalmology \& Visual Science, 53, 6442-6447.

Rehorek, S. J., Legenzoff, E. J., Carmody, K., Smith, T. D., \& Sedlmayr, J. C. (2005). Alligator tears: A re-evaluation of the lacrimal apparatus of the crocodilians. Journal of Morphology, 266, 298-308.

Rehorek, S. J., Smith, T. D., \& Bhatnagar, K. P. (2010). The orbitofacial glands of bats: An investigation of the potential correlation of gland structure with social organization. The Anatomical Record, 293(8), 1433-1448.

Saadi-Brenkia, O., Haniche, N., \& Bendjelloul, M. (2013). Light and electron microscopic studies of the Gerbillus tarabuli (Thomas, 1902) Harderian gland. Zoological Science, 30(1), 53-59.

Sabry, I., Al Azemi, M., \& Al Ghaith, L. (2000). The Harderian gland of the Cheesman's gerbil (Gerbillus cheesmani) of the Kuwaiti desert. European Journal of Morphology, 38, 97-108.

Saito, A., Watanabe, Y., \& Kotani, T. (2004). Morphologic changes of the anterior corneal epithelium caused by third eyelid removal in dogs. Veterinary Ophthalmology, 7, 113-119.

Sakai, T. (1981). The mammalian Harderian gland: Morphology, biochemistry, function and phylogeny. Archivum Histologicum Japonicum, 44, 299-333.

Sakai, T. (1989). Major ocular glands (Harderian gland and lacrimal gland) of the Musk Shrew (Suncus murinus) with a review on the comparative anatomy and histology of the mammalian lacrimal glands. Journal of Morphology, 201, 39-57.

Schlegel, T., Brehm, H., \& Amselgruber, W. M. (2001). The cartilage of the third eyelid: A comparative macroscopical and histological study in domestic animals. Annals of Anatomy, 183, 165-169.

Setzer, P. Y., Nichols, B. A., \& Dawson, C. R. (1987). Unusual structure of rat conjunctival epithelium. Light and electron microscopy. Investigative Ophthalmology \& Visual Science, 28, 531-537.

Sinha, R. D., \& Calhoun, M. L. (1966). A gross, histologic and histochemical study of the lacrimal apparatus of sheep and goats. American Journal of Veterinary Research, 27, 1633-1640.

Sisson, S., \& Grossman, J. D. (1974). Anatomia de 10s animals domesticos. $4 a$ ed. Salvat. Barcelona. 
Stern, M. E., Gao, J., Siemasko, K. F., Beuerman, R. W., \& Pflugfelder, S. C. (2004), The role of the lacrimal functional unit in the pathophysiology of dry eye. Experimental Eye Research, 78(3), 409-416.

Tiffany, J. M. (1987). The lipid secretion of the meibomian glands. Advances in Lipid Research, 22, 1-62.

Umeda, Y., Nakamura, S., Fujiki, K., Toshida, H., Saito, A., \& Murakami, A. (2010). Distribution of goblet cells and MUC5AC mRNA in the canine nictitating membrane. Experimental Eye Research, 91, 721-726.

Veiga Neto, E. R., Tamaga, O. J., Zorzetto, N. L., \& Dallpai, V. (1992). Anatomical aspects of the lacrimal gland of the tufted capuchin (Cebus apella). Journal of Anatomy, 180, 75-80.

Watanabe, M. (1980). An autoradiographic, biochemical and morpho-logical study of the Harderian gland of the mouse. Journal of Morphology, 163, 349365.

\section{Publisher's Note}

Springer Nature remains neutral with regard to jurisdictional claims in published maps and institutional affiliations.

\section{Submit your manuscript to a SpringerOpen ${ }^{\odot}$ journal and benefit from:}

- Convenient online submission

- Rigorous peer review

- Open access: articles freely available online

High visibility within the field

- Retaining the copyright to your article

Submit your next manuscript at $\boldsymbol{\wedge}$ springeropen.com 